\title{
Circumscription, diagnosis and description of a subfamily of Australo-Papuan robins
}

\author{
KATE LOYNES ${ }^{1}$, LEO JOSEPH ${ }^{2} \&$ J. SCOTT KEOGH ${ }^{1}$ \\ ${ }^{\prime}$ Division of Evolution, Ecology and Genetics, Building 116, Daley Rd, Research School of Biology, The Australian National \\ University, Canberra, ACT 0200 Australia \\ ${ }^{2}$ Australian National Wildlife Collection, CSIRO Ecosystem Sciences, GPO Box 1700, Canberra, ACT 2601, Australia; \\ email:Leo.Joseph@csiro.au
}

The family-group name Microecinae Loynes, Joseph and Keogh, 2009 was erected by Loynes et al. (2009) following their phylogenetic analysis of the Australo-Papuan robins (Aves: Passeriformes: Petroicidae). Loynes et al. (2009) assigned to Microecinae one genus Microeca Gould, 1840, which as conventionally construed (see Boles 2007) comprises six species (M. flavigaster, M. fascinans, M. griseoceps, M. hemixantha, M. flavovirescens, M. papuana) found in Australia, New Guinea and some surrounding islands (see Schodde and Mason 1999, Boles 2007 for details). Loynes et al. (2009) were able to include only the first three of those six species in their analysis. They did, however, transfer a further species from Eopsaltria to Microeca, which was thus recognized as M. flaviventris.

The name Microecinae was formed in accordance with Article 11.7 of ICZN (1999). It was erected with a clear statement that it included only Microeca as traditionally construed. It was also accompanied by a bibliographic reference to Boles (2007) as supporting the need for division of the subfamily Petroicinae to which Microeca had previously been assigned. Regrettably, however, the requirements of Article 13.1, specifically Article 13.1.1 of ICZN (1999) were not met. Article 13.1.1 indicates the need for a new familygroup name to be accompanied by a description or definition stating in words the characters that purportedly differentiate it. That the diagnostic traits of Microecinae were at best implied by Loynes et al. (2009) to be those of Microeca does not meet the criteria of Article 13.1.1 and so the name is unavailable. Given this, we here propose that Microecinae Loynes, Joseph and Keogh, 2009 be replaced by:

Microecinae Loynes, Joseph and Keogh, 2011 Australo-Papuan robins traditionally assigned to the genus Microeca including M. flaviventris (see Loynes et al. 2009) and characterized by traits listed in Schodde and Mason (1999) for Microeca as there construed: dorsally whitespotted juvenile plumages in which white spotting persists on thumb-wing coverts in first year birds, no red in any plumage phase, adult plumages characterized mostly by flavonoidpigmented tones, flattened bills with large rictal bristles, weak feet, unbarred remiges, and flat, saucer-shaped nests.. Type genus: Microeca Gould, 1840.

\section{Acknowledgements}

We thank R.B. Halliday, M. LeCroy, N.W. Longmore and R. Schodde for comments on a draft.

\section{Literature Cited}

Boles, W.E. (2007) Family Petroicidae (Australasian robins). Pp. 438-488. In: Del Hoyo, J., Elliot, A., \& Christie, A. 
(Eds.), Handbook of Birds of the World. Picathartes to Tits and Chickadees, vol. 12. Lynx Edicions, Barcelona. ICZN (International Code of Zoological Nomenclature) (1999) International Code of Zoological Nomenclature, Fourth Edition. International Trust for Zoological Nomenclature, London. xxix, 306 pp.

Loynes, K., Joseph, L. \& Keogh, J.S. (2009) Multi-locus phylogeny clarifies the systematics of the Australo-Papuan robins (Family Petroicidae, Passeriformes). Molecular Phylogenetics and Evolution, 53, 212-219.

Schodde, R., Mason, I.J. (1999) The directory of Australian birds. Passerines. CSIRO Publishing, Melbourne. 851 pp. 